Al-Azhar Bull. Sci. Vol. 18, No. 2 (Dec.): pp. 37-58, 2007.

\title{
BACTERIOLOGICAL SYSTEMS AS A NEW APPROACH FOR DESALINATION OF SALTY WATER
}

\author{
BAYOUMI, R.A.; LOUBOUDY, S.S.; EL-GAMAL, M.S.; ABDELWAHED, M.A. \\ Botany and Microbiology Dept., Faculty of Science(Boys), Al-Azhar University, \\ Madinet Nasr, Cairo, Egypt. P.N. 11884.
}

\begin{abstract}
Forty eight halotolerant microbial isolates were isolated from water and soil samples collected from Mediterranean sea (Alexandria), Ein-Helwan (Helwan), Red Sea (Hurghada), and Qarun lake (El-Fayoum). Soil samples were collected from Alexandria, Ein-Helwan, Qaron, El-Toor, and Sant-Katren. Three halotolerant bacterial isolates were chosen as the most potent halotolerant bacterial isolates for bacterial desalination of sea water. These isolates were identified as Sporohalobacter marisomartui BEW45, Marinococcus hispanicus BEW47 and Halomonas elongata BAW48. Combination of the three potent halotolerant bacterial isolates exhibited high desalination percentage. The highest desalination percentage (\%) was achieved at $37^{\circ} \mathrm{C}, \mathrm{pH} 6$, for $168 \mathrm{~h}$., inoculum size $2.5 \mathrm{ml}$ (each ml contain $67 \times 10^{7}$ cells, CFU), no tested carbon sources and yeast extract as best nitrogen source. The best bacterial desalination of sea water was performed by repeated recycling the sea water three times, by subjecting water to there potent halotolerant bacterial strains. The desalination percentage (\%) of $\mathrm{Ca}^{++}, \mathrm{Mg}^{++}, \mathrm{Cl}^{-}, \mathrm{Na}^{+}$and $\mathrm{K}^{+}$reached up to $88,78,79,76$ and $63 \%$ respectively. The resulted desalinated sea water was used in irrigation of Hordeum vulgare Giza 2. This study recommend the possibility of the selected strains to desalinate of salty water by designing of desalination plants similar to wastewater treatment plants to be used in irrigation of some economic crops and woody forest trees.
\end{abstract}

\section{Introduction}

Water is the most important of life sources that we need for our survival. It is necessary for growth of plants, and hydration of animals, which in turn are consumed by us. Human body contains approximately $60 \%$ water. The total amount of water on earth has remained almost constant over billions of years. Water in rivers is only about 1/10.000 of all earth's water. Yet, rivers are the source of most daily used water. High percent of the world water on earth is saline water. As water is a precious commodity, as wise that we try to conserve and limit our use as much as possible (Fetter, 2001). Desalination processes remove dissolved salts and other materials from sea water and brackish water. The principal desalination technologies in use are reverse osmosis(RO) and distillation. Electrodialysis and vacuum freezing also have some applications. Fresh water scarcity is already posing major problem for more than a billion people around the world, mostly in arid developing countries. Spang(2006) explores the global potential for integrity wind power and desalination 
technologies to increase water supplies. The World Heath Organization(HWO) predicts that by mid-century, four billion of us-nearly two-thirds of the World's present population-will face severe fresh water shortage. More than 11.000 desalination plants are in operation through the world producing more than 20 million cubic meters(roughly six billion gallons) of water per day and the number is growing. It has been estimated that there will be a $100 \%$ increase in the active installed capacity of desalination plants during the 2005-2015(Cotruvo, 2004;2007).In recent time, the pollution of seawater appears to be at a much higher level than in the past because of the explosion in industrial growth and the population observed all over the world. Considering this situation Yoshitaka et al., (2005) developed biological system, which is a new technology developed to overcome these pollution problems. The biological methods of desalination can be used in different area specially arid desert and island areas where large amounts of energy are not required. The cost of this methods is too little in comparison to other well established methods that need large amounts of energy, complex designs, technology with high costs. In the present study, we describe isolation, purification, characterization of the selected potent halotolerant bacterial isolates. Studying the parameters controlling the desalination process of sea water were also discussed.

\section{Materials and Methods}

\section{I- Media used:}

The following media were used for isolation, and purification of halotolerant microorganisms collected from water and soil samples.

\section{Modified Lockhead's Skim milk agar medium (SMA) (Ammar et al., 2000):}

This medium was used for isolation of halotolerant bacteria. It has the following composition (g/l): Skim milk powder, 50; $\mathrm{NaCl}, 100 ; \mathrm{MgSO}_{4} .7 \mathrm{H}_{2} \mathrm{O}, 20 ; \mathrm{Ca}\left(\mathrm{NO}_{3}\right)_{2}$, 2.5; yeast extract, 1 and agar, 20.Minerals were dissolved in the distilled water and sterilized. Yeast extract and milk were also sterilized. $\mathrm{pH}$ was adjusted at 7.5 before sterilization. The two solutions were mixed together after sterilization. Total volume was completed up to $1000 \mathrm{ml}$.

2. Medium routinely used in $H$. Larsen's laboratory for axenic culturing of halobacteriaceae (HCM) (Larsen, 1981):

This medium has the following composition (g/l): $\mathrm{NaCl}, 100 ; \mathrm{MgSO}_{4} 7 \mathrm{H}_{2} \mathrm{O}, 10$; $\mathrm{KCl}, 5 ; \mathrm{CaCl}_{2} 6 \mathrm{H}_{2} \mathrm{O}, 0.2$; yeast extract, 5; tryptone, 5; agar, 20 and distilled water up 
to $1000 \mathrm{ml}$. Salts and organic substances were sterilized separately and $\mathrm{pH}$ was adjusted at 7 .

\section{Sea water media:}

Three types of sea water media were used in this study viz. $1 \%$ peptone sea water, $1 \%$ yeast extract sea water and $1 \%$ sodium nitrate sea water media.

\section{II- Determination of some ions in sea water samples: chlorine, sodium, potassium, calcium and magnesium ions in sea water samples were determined as the following:-}

a- Determination of chloride $\left(\mathrm{Cl}^{-}\right)$ion was carried out by the Mohr's method (Jeffery et al., 1989):

Mohr's method was based on titration of halide, such as $\mathrm{NaCl}$ with $\mathrm{AgNO}_{3}$ solution in the presence of $\mathrm{K}_{2} \mathrm{Cr}_{2} \mathrm{O}_{2}$ as indicator. The end point of the titration was the point at which the color of the suspension changes from pure yellow to reddish brown.

b- Determination of sodium $\left(\mathrm{Na}^{+}\right)$and potassium $\left(\mathrm{K}^{+}\right)$ions:

Sodium $\left(\mathrm{Na}^{+}\right)$, and potassium $\left(\mathrm{K}^{+}\right)$ions were measured using a flame photometer model Corning 400.

c- Determination of calcium $\left(\mathrm{Ca}^{++}\right)$ion was carried out according to Jeffery et al., (1989):

Calcium ions were determined by using muroxide as indicator. In this method the saline water sample must changed to alkaline by addition of $(1 \mathrm{~N}) \mathrm{NaOH}$ and titrated with standard ethylene diamine tetra acetic acid (EDTA).

$d$ - Determination of magnesium $\left(\mathrm{Mg}^{++}\right)$ion was carried out according to Jeffery et al., (1989):

Magnesium water sample become alkaline by the addition of ammonia buffer mixture and titration was carried out with standard EDTA. The indicator, eriochrome black $\mathrm{T}$ (EBT) forms wine-red complexes with $\mathrm{Ca}^{++}$and $\mathrm{Mg}^{++}$ions. At the end point, the wine-red colour of the solution changes to blue colour. The volume of EDTA consumed in this method was equivalent to $\mathrm{Ca}^{++}$and $\mathrm{Mg}^{++}$, but the volume of EDTA consumed in determination of $\mathrm{Mg}^{++}$is equal to the difference between total volume EDTA consumed in determination of calcium and magnesium and the volume of EDTA consumed in determination of calcium only. 


\section{III- Selection of the best halotolerant microbial isolates:}

Growth of halotolerant microorganisms on medium containing high salt concentration: The total microbial isolates were grown on the surface of isolation media (HCM and SMA media) containing $10 \% \mathrm{NaCl}$. Growth of total microorganisms were tested on the same medium but containing different concentrations of $\mathrm{NaCl}$ viz.15, 20, 25 and $30 \%$ to select the potent halotolerant microorganisms that could tolerate high level of $\mathrm{NaCl}$.

VI- Desalination by using the best halotolerant bacterial isolates: Three saline water samples collected from different localities (Hurghada, Qarun, and Alexandria) were inoculated by the most halotolerant bacterial isolates to proof the tolerance of these bacteria towards high salt levels of saline water samples. Yeast extract sea water medium was inoculated by the potent bacterial isolates, and incubated at $37^{\circ} \mathrm{C}$ for 7 days. At the end of the incubation period, the concentrations of $\mathrm{Ca}^{++}, \mathrm{Mg}^{++}, \mathrm{Cl}^{-}$, $\mathrm{Na}^{+}$and $\mathrm{K}^{+}$were determined before and after desalination process of sea water samples. Concentration of $\mathrm{Ca}^{++}, \mathrm{Mg}^{++}$and $\mathrm{Cl}^{-}$, were determined by titration (Jeffery et al., 1989) method while $\mathrm{Na}^{+}$and $\mathrm{K}^{+}$were determined by flame photometer (Muharram,2000). Bacterial protein content was also determined by Folin-Phenol reagent (Lowry et al., 1951).

VII- Effect of combined action among potent bacterial isolates on the desalination of sea water: Four combinations among potent bacterial isolates were performed by washing the culture with saline solution under aseptic conditions. Yeast extract sea water medium was inoculated by each combination. At the end of each incubation period, rates of $\mathrm{Ca}^{++}, \mathrm{Mg}^{++}$and $\mathrm{Cl}^{-}$, were determined by the titration method while $\mathrm{Na}^{+}$and $\mathrm{K}^{+}$were determined by flame photometer.

VIII-Identification of the three potent halotolerant bacterial isolates: Three potent halotolerant bacterial isolates were identified on of basis of various morphological, physiological, and biochemical characteristics following the criteria laid down in Bergey's Manual of Determinative Bacteriology (Holt et al., 1994).

IX- Parameters controlling desalination process and optimization of some nutritional and environmental conditions for the three most potent halotolerant bacterial isolates:- Following each factor performance, protein content was determined by Folin-Phenol reagent method (Lowry et al.,1951)and concentration of 
$\mathrm{Cl}^{-}, \mathrm{Ca}^{++}$and $\mathrm{Mg}^{++}$were also determined by titration which finally $\mathrm{Na}^{+}$and $\mathrm{K}^{+}$were determined by flame photometer.

1- Effect of different incubation periods was carried out by allowing the potent bacterial isolates to grow on yeast extract sea water medium incubated at different incubation periods.

2- Effect of different incubation temperatures was carried out by inoculating yeast extract sea water medium with the three potent halotolerant bacterial isolates separately or in combination and were incubated at different incubation temperatures.

3- Effect of different $\mathrm{pH}$ values:

Range from 3 - 10 was designed by using (1N) $\mathrm{NaOH}$ and (1N) $\mathrm{HCl}$ for sea water and inoculated by bacterial suspension.

4- Effect of inoculum size:

Different inoculum sizes of bacterial suspension were incubated individually or in combination among the most tolerant bacterial isolates.

5- Effect of different nitrogen sources:

Different nitrogen sources were added at a level of $(1 \%, \mathrm{w} / \mathrm{w})$ to sea water and inoculated by the optimal inoculum size suspension of the potent combination among the three bacterial isolates. The nitrogen sources that were applied included ammonium oxalate, ammonium nitrate, ammonium sulphate, urea, ammonium acetate, peptone, potassium nitrate, ammonium chloride, ammonium dihydrogen orthophosphate and yeast extract.

6- Effect of different carbon sources:

Different carbon sources were added to sea water at concentration $(1 \%, \mathrm{w} / \mathrm{w})$. The carbon sources were represented by glucose, lactose, galactose, fructose, raffinose, starch, cellobiose, cellulose, sucrose, glycerol, sorbitol, mamito, and xylose.

7- Effect of aeration conditions:

This experiment was carried out to investigate the effect of shaking or static condition on the desalination of sea water by the bacterial isolates. 


\section{XI-Effect of different doses of UV irradiation on sea water desalination:}

The most halotolerant bacterial isolates were exposed to UV radiation at $365 \mathrm{~nm}$ for 2, 5, 10 and $15 \mathrm{~min}$. Sea water medium was inoculated by bacterial isolates after UV treatment and incubated for 7 days under all optimal conditions.

XII- Bacterial desalination of sea water: Sea water was treated by the most potent bacterial combination under all optimal conditions, this was carried out by repeating desalination process for three times. In the first step of treatment, sea water medium was inoculated by the potent bacterial combination and incubated under all optimal conditions for 7 days. At the end of incubation period, treated sea water was centrifuged to remove bacterial cells, the supernatant sea water was used in the second step of treatment. In this step, pre-treated sea water was also inoculated by the same potent bacterial isolates. At the end of incubation period treated sea water was centrifuged to be prepared for the third desalination treatment step. During the third treatment step, $100 \mathrm{ml}$ of the treated water which was obtained from second treatment was re-inoculated, then incubated as in the previous two treatment steps. Concentration of $\mathrm{Cl}^{-}, \mathrm{Ca}^{++}, \mathrm{Na}^{+}, \mathrm{K}^{+}$and $\mathrm{Mg}^{+}$were determined at the end of the last incubation period.

\section{RESULTS}

Twenty two and twenty five bacterial isolates were isolated from water and soil samples respectively on HCM medium. Only one fungal isolate was isolated from soil sample FQS24 on SMA medium. Code numbers, source and localities and the halotolerant isolates are recorded in table (1). All forty-eight halotolerant microbial isolates grew well on HCM and SMA media supplemented with $10 \% \mathrm{NaCl}$. Thirty two isolates succeeded to grow on HCM medium containing $25 \% \mathrm{NaCl}$. The results showed in table (2) also that twenty two microbial isolates thrived at $30 \% \mathrm{NaCl}$. Fifteen halotolerant bacterial isolates were selected as the most halotolerant isolates which showed good growth at $25 \% \mathrm{NaCl}$ and moderately or weakly grew at $30 \%$ $\mathrm{NaCl}$.

Eight halotolerant bacterial isolates were selected for the previously fifteen which grew at 25 and $30 \% \mathrm{NaCl}$ according to their high total protein content and vigorous growth. Six isolates were selected due to their ability to grow on peptone sea water and yeast extract sea water media, these isolates were BQW27, BHW34, 
BEW40, BEW45, BAS47 and BAW48. Yeast extract sea water medium gave high bacterial protein content as compared to peptone sea water medium. Results recorded in table (3) showed that the maximum amount of protein content was obtained by BEW45 growing on sea water of Alexandria followed by the same isolate on sea water of Qarun lake, whereas BQW27 exhibited significant growth when grown on Red sea water, followed by bacterial isolate BEW40 and BHW34 growing on Red sea water (Hurghada) medium. Three bacterial isolates were chosen as the potent halotolerant bacterial isolates viz. BEW45, BAS47 and BAW48 which gave the highest reduction value of most salt ions in sea water (removal percentage \%). Desalination value by BEW45 as $\mathrm{Ca}^{++}, \mathrm{Mg}^{++}, \mathrm{Cl}^{-}, \mathrm{Na}^{+}$and $\mathrm{K}^{+}$concentrations percentage in case of Qarun water were recorded values up to 63,61,47,61, and $20 \%$ respectively. BAS47 recorded removal percentage (\%) were 72,11,11,51 and 49\% respectively, while in case of BAW48 showed removal percentages (\%) 45, 19,0, and $0 \%$ respectively. In case of Mediterranean sea water, desalination by BEW45 as $\mathrm{Ca}^{++}, \mathrm{Mg}^{++}, \mathrm{Cl}^{-}, \mathrm{Na}^{+}$and $\mathrm{K}^{+}$salt ions removal percentage(\%)obtained at levels of $83,47,36,26$, and $25 \%$ respectively. Results recorded in table (4) and presented graphically in figure (1) showed that, the combination of BEW45, BAS47, and BAW48 was the most optimum combination favorable for sea water desalination. At this combination $\mathrm{Ca}^{++}, \mathrm{Mg}^{++}, \mathrm{Cl}^{-}, \mathrm{Na}^{+}$, and $\mathrm{K}^{+}$concentrations recorded as $401,2575,16437$, and $676 \mathrm{mg} / \mathrm{l}$, respectively and ion removal percentage (\%) achieved $34,11,8,5$ and $46 \%$ respectively.

Identification of the three potent halotolerant bacterial isolates: Preliminary examination of the three potent halotolerant bacterial isolates on the bases of cell shape and arrangement, Gram reaction, and oxygen requirement were divided into three groups as follow: Group (A): Aerobic Gram-positive bacilli; Group (B): Aerobic Gram -positive cocci and Group (3): Aerobic Gram -negative bacilli. Using Bergey's Manual of Determinative Bacteriology (Holt et al., 1994), these halotolerant bacterial isolates were suggested to be belonging to Sporohalobacter marismortui ; Marinococcus hispanicus and Halomonas elongata, thus they could be given the tentatively identified as Sporohalobacter marismortuiBEW45; Marinococcus hispanicusBAS47; and Halomonas elongata BAW48. 
Parameters controlling desalination process and optimization of some nutritional and environmental conditions for the three potent halotolerant bacterial isolates:

Since Sporohalobacter marismortui BEW45, Marinococcus hispanicus BAS47 and Halomonas elongata BAW48 proved to be the potent bacterial strains, they were selected purposely for investigating some factors affecting desalination of sea water under laboratory conditions. Such factors included: incubation period, incubation temperature, $\mathrm{pH}$, inoculum size and supplementation of different carbon and nitrogen sources and then evaluating the sea water desalination by applying all the previously determined optimal conditions. Optimum incubation period was 168 hr. At this incubation period, the concentration of $\mathrm{Ca}^{++}, \mathrm{Mg}^{++}, \mathrm{Cl}^{-}, \mathrm{Na}^{+}$and $\mathrm{K}^{+}$in sea water were 414, 2911, 19619, 10533 and $1451 \mathrm{mg} / \mathrm{l}$ respectively in comparable with control and total protein content $(\mathrm{mg} / \mathrm{ml})$ was $0.426 \pm 0.036$. Also, the salts reduction value (\%) of $\mathrm{Ca}^{++}, \mathrm{Mg}^{++}, \mathrm{Cl}^{-}, \mathrm{Na}^{+}$and $\mathrm{K}^{+}$were $19,7,0.3,8$, and 45 respectively. Interestingly, the fact that this bacterial combination which was allowed to grow on sea water samples exhibited its maximum ability to sea water desalination by incubation at $37^{\circ} \mathrm{C}$, at this particular temperature the concentrations of $\mathrm{Ca}^{++}, \mathrm{Mg}^{++}$, $\mathrm{Cl}^{-}, \mathrm{Na}^{+}$and $\mathrm{K}^{+}$were 321, 2623, 19674, 11204 and $998 \mathrm{mg} / \mathrm{l}$ respectively and the total cell protein content $(\mathrm{mg} / \mathrm{ml})$ was $0.411 \pm 0.028$, where the ions removal $(\%)$ for $\mathrm{Ca}^{++}, \mathrm{Mg}^{++}, \mathrm{Cl}^{-}, \mathrm{Na}^{+}$and $\mathrm{K}^{+}$were 43, 15, 4, 12 and 7 respectively. Also, it was found that $\mathrm{pH} 6.0$ was the optimum $\mathrm{pH}$ for desalination by combination among the three potent bacterial strains. At this particular $\mathrm{pH}$, the concentrations of $\mathrm{Ca}^{++}, \mathrm{Mg}^{++}, \mathrm{Cl}^{-}$, $\mathrm{Na}^{+}$, and $\mathrm{K}^{+}$were 400, 2255, 16661, 12692 and $870 \mathrm{mg} / \mathrm{l}$ respectively, and bacterial protein content was $0.337 \pm 0.023$, where the removal of ions (\%) for $\mathrm{Ca}^{++}, \mathrm{Mg}^{++}, \mathrm{Cl}^{-}$, $\mathrm{Na}^{+}$and $\mathrm{K}^{+}$were 49,24, 15, 2 and 20 respectively. It was found that the most optimum inoculum size enhancing sea water desalination by combination among the three potent bacterial isolates was $2.5 \mathrm{ml}$ of the bacterial suspension. At this particular inoculum size, the concentrations of $\mathrm{Ca}^{++}, \mathrm{Mg}^{++}, \mathrm{Cl}^{-}, \mathrm{Na}^{+}$and $\mathrm{K}^{+}$were in the range of 500, 3015, 18788, 11785 and 882 (mg/l) respectively. The highest ions reduction value $(\%)$ of $\mathrm{Ca}^{++}, \mathrm{Mg}^{++}, \mathrm{Cl}^{-}, \mathrm{Na}^{+}$, and $\mathrm{K}^{+}$were also found to be 43,11 , $8.6,7$ and 7.3 respectively. Total protein content $(\mathrm{mg} / \mathrm{ml})$ was $0.364 \pm 0.016(\mathrm{mg} / \mathrm{ml})$ with inoculum size $2.5 \mathrm{ml}$. In addition, it was found that the optimum nitrogen source was yeast extract by combination among S. marismortui BEW45, M. hispanicus BAS47, and $H$. elongata BAW48 for desalination of sea water which gave higher reduction value of sea water ions than other nitrogen sources. The concentrations of 
$\mathrm{Ca}^{++}, \mathrm{Mg}^{++}, \mathrm{Cl}^{-}, \mathrm{Na}^{+}$, and $\mathrm{K}^{+}$were $350,2982,20383,11820$ and $956(\mathrm{mg} / \mathrm{l})$ respectively and total bacterial protein content was $0.313 \pm 0.017$. The ions reduction value (\%) for $\mathrm{Ca}^{++}, \mathrm{Mg}^{++}, \mathrm{Cl}^{-}, \mathrm{Na}^{+}$and $\mathrm{K}^{+}$were found to be 53, 8.5, 8.7, 9.1, and 1.1 respectively. All tested carbon sources not exhibited any increase in reduction value of ions in sea water. By incubation under shaking condition the concentrations of $\mathrm{Ca}^{++}, \mathrm{Mg}^{++}, \mathrm{Cl}^{-}, \mathrm{Na}^{+}$, and $\mathrm{K}^{+}$in sea water were 437, 2492, 15302, 6982, and 665 $\mathrm{mg} / \mathrm{l}$ respectively. The reduction value $(\%)$ for $\mathrm{Ca}^{++}, \mathrm{Mg}^{++}, \mathrm{Cl}^{-}, \mathrm{Na}^{+}$and $\mathrm{K}^{+}$were 51 , $26,26,45$, and 30 respectively and the total bacterial protein at shaking conditions was $0.341 \pm 0.008(\mathrm{mg} / \mathrm{ml})$ (Tables 5and6).

Effect of ultra violet (UV) irradiation on combination of S. marismortui BEW45, M. hispanicus BAS47 and H. elongata BAW48 on desalination of sea water:

In fact, all the present results proved that UV could be considered as mutagenic agent for a combination among S. marismortui BEW45, M. hispanicus BAS47 and H. elongata BAW48 without any significant changes for their ability on the desalination process of sea water (Figure 2).

Repeated recycling of sea water by a combination of halotolerant bacterial isolates:

Results recorded in table (6), and represented graphically in figure (3), after the first step of bacterial desalination $\mathrm{Ca}^{++}, \mathrm{Mg}^{++}, \mathrm{Cl}^{-}, \mathrm{Na}^{+}$and $\mathrm{K}^{+}$concentration of sea water were 489, 2458, 15638, 7247 and $668(\mathrm{mg} / \mathrm{l})$ respectively, and the reduction value $(\%)$ were $48,35,37,39$, and 32 respectively. After the second step of bacterial desalination $\mathrm{Ca}^{++}, \mathrm{Mg}^{++}, \mathrm{Cl}^{-}, \mathrm{Na}^{+}$and $\mathrm{K}^{+}$concentrations of sea achieved value of $197,1247,7943,3445$ and 423 (mg/l) respectively, and the reduction values (\%) obtained were $79,67,68,71$ and 57 respectively. After the third step of bacterial desalination, $\mathrm{Ca}^{++}, \mathrm{Mg}^{++}, \mathrm{Cl}^{-}, \mathrm{Na}^{+}$and $\mathrm{K}^{+}$concentrations of sea water were 113,832 , 5213,2832 and $315(\mathrm{mg} / \mathrm{l})$ respectively, and the reduction value $(\%)$ were 88,78 , 79,76 , and 68 respectively. It was clear that the reduction value $(\%)$ for $\mathrm{Ca}^{++}$was 48 and increased to $88 \%$ after the third desalination step, $\mathrm{Mg}^{++}$was $35 \%$ and achieved of $78 \%$ by performance of the third step, $\mathrm{Cl}^{-}$was $37 \%$ and reached up to $79 \%$ after carrying out the third desalination step, $\mathrm{Na}^{+}$was $39 \%$ which give a value of $76 \%$ at the end of the third step, and $\mathrm{K}^{+}$was $32 \%$ and reached up to $63 \%$ after the final bacterial desalination step. 


\section{Application of halotolerant bacterial desalinated of sea water strains in the irrigation of Hordeum vulgare in experimental fields :-}

The desalinated water was used in irrigation of Hordeum vulgare Giza 2 which is characterized by growth in fewer amount of water under salt stress. As shown in table (8) the control shoot length was $5.7 \pm 0.264 \mathrm{~cm}$ but in case of plants irrigated by recycled treated sea water were $4.863 \pm 123$. The root length of control plant was $10.66 \pm 0.104 \mathrm{~cm}$. but in case of plants irrigated by the treated sea water were $6.633 \pm 0.55$. Chlorophyll (a) content for control plants was $7.7 \pm 0.173 \mathrm{mg} / \mathrm{g}$ whereas the same for test plants was $6.1 \pm 0.0404(\mathrm{mg} / \mathrm{g})$. Also chlorophyll (b) content for control plants was $4.43 \pm 0.02(\mathrm{mg} / \mathrm{g})$ while for treated plants was $4.41 \pm 0.242(\mathrm{mg} / \mathrm{g})$. Finally carotenoid content recorded $2.5 \pm 0.264(\mathrm{mg} / \mathrm{g})$ for control plants while for test plants was $2.173 \pm 0.125(\mathrm{mg} / \mathrm{g})$. It was found that irrigation with microbiologically desalinated sea water did not vary remarkably from that of the tap water.

\section{Discussion}

The population of the world has been greatly increasing water is the limiting factor for life in the universe. Although, covers about three quarters of the earth's surface, only $3 \%$ is fresh water from various sources. Thus, water treatment is usually needed, and the desalination process is the most efficient method for obtaining fresh water from sea water. Few years ago attempts were made for utilizing power plants in sea water desalination which was one of the modern trends to overcome the gap between the increasing water demands and the shortage in water resources in the world. There were few number of studies on microbiological desalination of salty water using a microbiological system. Accordingly the present study was conducted mainly to eliminate salts from saline water using a microbiological system. The most potent in the present study were identified as Sporohalobacter marisomartui BEW45, Marinococcus hispanicus BEW47 and Halomonas elongata BAW48. Das-Sarma and Arora(2001) mentioned examples of most widely distributed halophilic microorganisms include Halobacterium sp., Marinococcus, Bacillus, Salinococcus and Tetragenococcus. In a recent study, it become clear that the abundance of bacterial communities in the highly saline environments is comparable to those found in the normal marine zones. To be able 
to live at high salt concentrations, halophilic and halotolerant organisms must maintain a cytoplasm that is osmotically isotonic with the outside medium (Dennis and Shimmin,1997; Ventosa et al.,1998).Halophilic posses many hydrolytic enzymes such as DNAses, lipases, amylases, gelatinases and proteases capable of functioning under conditions that lead to precipitation of most proteins (Das-Sarma and Arora,2001; Kirkar, 2004). Although the current commercial uses of the halophiles are quite significant and many novel and unique properties of many of these organisms, suggest that they have even greater potential for desalination biotechnology.

Qasim (1999) and Qasim et al., (2000) showed that the removal of total dissolved solids from water was described as desalination, desalting or salt waterconversion. The desalination factories in Egypt are rare in comparison to Saudi Arabia and Kuwait; because costs of the desalination are generally higher than the costs of other water supply alternatives (e.g. water transfer and groundwater pumping). The growing potable water demand in Red Sea and Sinai resorts lead to organize a national plan for implementation of desalination technology. In accordance to our results, Kargi and Dincer, (1998) used halotolerant bacteria viz. Halobacter halobium supplemented with activated sludge culture in saline wastewater treatment in aerated rotating bidisc contactor. In addition, Ammar and Muharram (1998) and Ammar et al.,(2000) studied the application of microbial biotechnology in sea water desalination and used five different fungal isolates belonging to Aspergillus fumigatus. The present results were in agreement to some extent with those obtained by Gandbhir et al., (1995) who mentioned that, Haloferax mediterranei required high salt concentrations for growth while Halomonas elongata, a halotolerant eubacterium was able to grow at any salt concentrations. Similar results were reported by Patel et al., (1993) who found that halophilic Halobacterium halobium S9 grew well on media containing $25 \% \mathrm{NaCl}$. It has been reported that, Halomonas elongata was able to live in a wide range of salt concentration $(0.05-3.4 \mathrm{M})$, because it versatile cell physiology in ways which increased the structural integrity of walls and increased amount of negatively charged lipids (Vreeland et al., 1991). In agreement to the present results, Blum et al., (2001) showed that proteins, peptones and some amino acids (asparagine, proline, and glutamic acid ) supported good growth with halotolerant and halophilic bacteria. Similar results were obtained by Oren (1995) who found that the 
respiratory activity was stimulated more than two folds by addition of glycerol, but not by the addition of any of other carbon source tested, including sugars, organic acids, and amino acids, or by addition of inorganic nutrients. A similar respiratory activity was also found by diluting the Dead Sea water samples with distilled water and incubation in light. In addition, Studdert et al.,(1997) used a medium containing $2 \%$ yeast extract, and $20 \% \mathrm{NaCl}$ for studying haloalkalophilic bacterial species. Johnsen et al., (2001) isolated some halophilic and halotolerant bacterial isolates utilizing peptides, yeast extract and proteins as carbon sources. Blum et al., (2001) isolated some halotolerant isolates using some components of the yeast extract as electron donor. It was obvious that, the bacterial desalination process by recycling of the sea water several times through the three repeated desalination process was much better for desalination of sea water. In an attempts to discuss the resistance of bacteria to high salt concentration, several investigations showed that bacteria allowed growth at high salinity, accumulate one or more specific solutes in the cell. Thus bacteria contradict the out flow of water molecules by the accumulation of these solutes which are called compatible solutes or organic osmolytes, thus, bacteria can adapt themselves to high osmolarity environment. This stress reaction generally referred to as osmoregulation or osmoadaptation, and aimed to maintain turgor and volume within boundaries acceptable for normal cellular physiology. The primary response to osmotic stress in bacteria is mainly the accumulation of $\mathrm{K}^{+}$ions. Potassium is a major cytoplasmic cation in growing bacterial cell and play an important role in cell physiology. Cellular $\mathrm{K}^{+}$activates various cytoplasmic enzymes and is required for protein synthesis. For these physiological processes, bacteria had evolved diverse potassium transport system. It was reported that potassium and ammonium ions exert stimulatory effect upon glucose fermentation activity. Magnesium play several important metabolic functions in the production and transport of energy. Magnesium is involved in the synthesis of protein, and it assist in the functioning of some enzymes. All of these results throw light upon the significance of bacterial desalination of sea water as a good objective in sea water desalination. Due to the lack information's about the desalination of sea water through the microbial system, it is beneficial to perform further investigations in this vital field. After all, the sooner this technology is transferred from ideas on paper to projects in the field, the sooner that target populations can start to benefit from improved access to water. 
Table (1): Halotolerant microbial isolates obtained from four water and five soil samples on HCM and SMA media.

\begin{tabular}{|c|c|c|c|c|c|}
\hline \multirow{2}{*}{$\begin{array}{c}\text { Isolate } \\
\text { no. }\end{array}$} & \multicolumn{2}{|c|}{ Water isolates. } & \multirow{2}{*}{$\begin{array}{c}\text { Isolate } \\
\text { no. }\end{array}$} & \multicolumn{2}{|c|}{ Soil isolates. } \\
\hline & Code no. & $\begin{array}{c}\text { Sample collection } \\
\text { localities }\end{array}$ & & $\begin{array}{l}\text { Code } \\
\text { no. }\end{array}$ & $\begin{array}{c}\text { Sample collection } \\
\text { localities }\end{array}$ \\
\hline 1 & BAW48 & Alexandria & 23 & BAS25 & \multirow{2}{*}{ Alexandria } \\
\hline 2 & BEW39 & \multirow{8}{*}{ Ein-Helwan } & 24 & BAS47 & \\
\hline 3 & BEW40 & & 25 & BTS4 & El-Toor \\
\hline 4 & BEW41 & & 26 & BES9 & \multirow{6}{*}{ Ein-Helwan } \\
\hline 5 & BEW42 & & 27 & BES10 & \\
\hline 6 & BEW43 & & 28 & BES19 & \\
\hline 7 & BEW44 & & 29 & BES20 & \\
\hline 8 & BEW45 & & 30 & BES21 & \\
\hline 9 & BEW46 & & 31 & BES23 & \\
\hline 10 & BHW31 & \multirow{4}{*}{ Hurghada } & 32 & BSS11 & \multirow{4}{*}{ Saint-Katren } \\
\hline 11 & BHW32 & & 33 & BSS12 & \\
\hline 12 & BHW34 & & 34 & BSS13 & \\
\hline 13 & BHW35 & & 35 & BSS14 & \\
\hline 14 & BQW26 & \multirow{9}{*}{ Qarun lake } & 36 & BQS1 & \multirow{13}{*}{ Qarun lake } \\
\hline 15 & BQW27 & & 37 & BQS2 & \\
\hline 16 & BQW28 & & 38 & BQS3 & \\
\hline 17 & BQW29 & & 39 & BQS5 & \\
\hline 18 & BQW30 & & 40 & BQS6 & \\
\hline 19 & BQW33 & & 41 & BQS7 & \\
\hline 20 & BQW36 & & 42 & BQS8 & \\
\hline 21 & BQW37 & & 43 & BQS15 & \\
\hline 22 & BQW38 & & 44 & BQS16 & \\
\hline & & & 45 & BQS17 & \\
\hline & & & 46 & BQS18 & \\
\hline & & & 47 & BQS22 & \\
\hline & & & 48 & FQS24 & \\
\hline
\end{tabular}

BAW and BAS: Bacteria isolated from Alex. Sea water, and soil samples.

BQW and BQS: Bacteria isolated from Qarun lake water, and soil samples.

BEW and BES: Bacteria isolated from Ein-Helwan water, and soil samples.

BHW: Bacteria isolated from Hurghada sea water sample.

FQS: Fungus isolated from Qarun soil sample.

BTS: Bacteria isolated from El-Toor soil sample.

BSS: Bacteria isolated from Saint-Katren soil sample. 
Table (2): Qualitative growth estimation of the forty eight halotolerant microbial isolates at different concentrations of sodium chloride (\%).

\begin{tabular}{|c|c|c|c|c|c|c|c|}
\hline \multirow{2}{*}{ No. } & \multirow{2}{*}{$\begin{array}{l}\text { Microbial } \\
\text { code number. }\end{array}$} & \multicolumn{6}{|c|}{$\mathrm{NaCl}$ concentrations (\%). } \\
\hline & & 10 & 15 & 20 & 25 & 30 & 35 \\
\hline 1 & BQS 1 & GG & GG & GG & GG & MG & $\mathrm{NG}$ \\
\hline 2 & BQS 2 & G & WG & NG & NG & NG & NG \\
\hline 3 & BQS 3 & MG & G & NG & NG & NG & NG \\
\hline 4 & BTS 4 & GG & GG & G & G & WG & NG \\
\hline 5 & BQS 5 & GG & MG & WG & NG & NG & NG \\
\hline 6 & BQS 6 & G & WG & NG & NG & NG & NG \\
\hline 7 & BQS 7 & GG & MG & G & NG & NG & $\mathrm{NG}$ \\
\hline 8 & BQS 8 & GG & MG & WG & WG & NG & $\mathrm{NG}$ \\
\hline 9 & BES 9 & G & WG & NG & NG & NG & NG \\
\hline 10 & BES 10 & GG & MG & WG & WG & NG & NG \\
\hline 11 & BSS 11 & MG & G & NG & NG & NG & NG \\
\hline 12 & BSS 12 & G & NG & NG & NG & NG & $\mathrm{NG}$ \\
\hline 13 & BSS 13 & GG & MG & WG & WG & NG & NG \\
\hline 14 & BSS 14 & GG & GG & G & G & NG & NG \\
\hline 15 & BQS 15 & GG & MG & WG & G & NG & NG \\
\hline 16 & BQS 16 & GG & GG & MG & MG & WG & NG \\
\hline 17 & BQS 17 & GG & MG & MG & MG & G & NG \\
\hline 18 & BQS 18 & MG & G & NG & NG & NG & NG \\
\hline 19 & BES 19 & G & WG & NG & NG & NG & NG \\
\hline 20 & BES 20 & MG & MG & MG & G & NG & NG \\
\hline 21 & BES 21 & G & WG & NG & NG & NG & NG \\
\hline 22 & BQS 22 & GG & GG & G & G & NG & $\mathrm{NG}$ \\
\hline 23 & BES 23 & G & NG & NG & NG & NG & NG \\
\hline 24 & FQS 24 & G & NG & NG & NG & NG & NG \\
\hline 25 & BAS 25 & GG & GG & GG & GG & WG & NG \\
\hline 26 & BQW 26 & GG & GG & MG & G & NG & NG \\
\hline 27 & BQW 27 & GG & GG & GG & GG & WG & NG \\
\hline 28 & BQW 28 & GG & GG & GG & GG & WG & NG \\
\hline 29 & BQW 29 & G & NG & NG & NG & NG & NG \\
\hline 30 & BQW 30 & GG & GG & MG & MG & G & NG \\
\hline 31 & BHW 31 & GG & GG & GG & GG & MG & NG \\
\hline
\end{tabular}


Table (2): Cont.

\begin{tabular}{||c|c|c|c|c|c|c|c||}
\hline \multirow{2}{*}{ No. } & \multirow{2}{*}{$\begin{array}{c}\text { Microbial } \\
\text { code number. }\end{array}$} & \multicolumn{6}{|c|}{ NaCl concentrations (\%). } \\
\cline { 3 - 8 } 32 & BHW 32 & GG & GG & GG & MG & G & NG \\
\hline 33 & BQW 33 & GG & GG & GG & GG & G & NG \\
\hline 34 & BHW 34 & GG & GG & GG & GG & G & NG \\
\hline 35 & BHW 35 & GG & GG & GG & MG & NG & NG \\
\hline 36 & BQW 36 & GG & GG & GG & GG & G & NG \\
\hline 37 & BQW 37 & GG & MG & NG & NG & NG & NG \\
\hline 38 & BQW 38 & GG & GG & MG & MG & WG & NG \\
\hline 39 & BEW 39 & GG & GG & MG & MG & WG & NG \\
\hline 40 & BEW 40 & GG & GG & GG & GG & WG & NG \\
\hline 41 & BEW 41 & GG & GG & GG & GG & G & NG \\
\hline 42 & BEW 42 & GG & GG & NG & WG & NG & NG \\
\hline 43 & BEW 43 & GG & GG & GG & GG & G & NG \\
\hline 44 & BEW 44 & GG & MG & G & NG & NG & NG \\
\hline 45 & BEW 45 & GG & GG & GG & GG & MG & NG \\
\hline 46 & BEW 46 & GG & GG & GG & GG & MG & NG \\
\hline 47 & BAS 47 & GG & GG & GG & GG & G & NG \\
\hline 48 & BAW 48 & GG & GG & GG & GG & WG & NG \\
\hline & Total number & 48 & 44 & 34 & 32 & 22 & 0 \\
\hline Percentage $\%)$. & 100 & 91.66 & 70.83 & 66.66 & 45.83 & 0 \\
\hline \hline
\end{tabular}

GG: Good growth. MG: Moderate growth G: Growth. WG: Weak growth. NG: No growth.

Table (3): Determination of the bacterial protein content of the best six halotolerant bacterial isolates.

\begin{tabular}{|c|c|c|c|c||}
\hline \multirow{2}{*}{ No. } & \multirow{2}{*}{ Isolates } & \multicolumn{3}{|c|}{ Total protein content $(\mathrm{mg} / \mathrm{ml})$} \\
\cline { 3 - 5 } & & $\begin{array}{c}\text { Red sea } \\
\text { (Hurghada) }\end{array}$ & $\begin{array}{c}\text { Qarun lake } \\
\text { (El-Fayoum) }\end{array}$ & $\begin{array}{c}\text { Mediterranean } \\
\text { (Alexandria) }\end{array}$ \\
\hline 1 & BQW 27 & $0.456 \pm 0.045$ & $0.286 \pm 0.023$ & $0.280 \pm 0.028$ \\
\hline 2 & BHW 34 & $0.372 \pm 0.009$ & $0.190 \pm 0.015$ & $0.272 \pm 0.019$ \\
\hline 3 & BEW 40 & $0.386 \pm 0.070$ & $0.364 \pm 0.021$ & $0.246 \pm 0.006$ \\
\hline 4 & BEW 45 & $0.347 \pm 0.023$ & $0.480 \pm 0.015$ & $0.530 \pm 0.027$ \\
\hline 5 & BAS 47 & $0.279 \pm 0.026$ & $0.326 \pm 0.124$ & $0.324 \pm 0.047$ \\
\hline 6 & BAW 48 & $0.176 \pm 0.029$ & $0.308 \pm 0.008$ & $0.360 \pm 0.025$ \\
\hline
\end{tabular}


Table (4): Determination of ions concentrations and bacterial protein content in sea water samples after desalination.

\begin{tabular}{||c|c|c|c|c|c|c|c||}
\hline \multirow{2}{*}{ No. } & \multirow{2}{*}{$\begin{array}{c}\text { Code number of } \\
\text { bacterial isolate. }\end{array}$} & \multicolumn{5}{|c|}{ Ion concentration $(\mathrm{mg} / \mathrm{l})}$. & \multirow{2}{*}{$\begin{array}{c}\text { Total protein } \\
\text { content } \\
(\mathrm{mg} / \mathrm{ml}) .\end{array}$} \\
\cline { 2 - 8 } & Control & 611 & 2909 & 17902 & 8460 & 1262 & 0.0 \\
\hline & BEW 45 & 421 & 2618 & 17364 & 8206 & 909 & $0.360 \pm 0.03$ \\
\hline 1 & BAS 47 & 513 & 2647 & 17364 & 8290 & 971 & $0.305 \pm 0.01$ \\
\hline 2 & BAW 48 & 439 & 2676 & 17185 & 8290 & 984 & $0.402 \pm 0.02$ \\
\hline 3 & 437 & 2610 & 17257 & 8290 & 857 & $0.603 \pm 0.051$ \\
\hline 4 & BEW45 and BAS47 & 437 & $\mathrm{Cl}^{-}$ & $\mathrm{Na}^{+}$ & $\mathrm{K}^{+}$ & \\
\hline 5 & BAS47 and BAW48 & 434 & 2675 & 16980 & 8333 & 740 & $0.409 \pm 0.008$ \\
\hline 6 & BAW48 and BE45 & 457 & 2765 & 17164 & 8119 & 841 & $0.360 \pm 0.038$ \\
\hline 7 & BEW45, BAS47 and & 401 & 2575 & 16437 & 8037 & 676 & $0.413 \pm 0.003$ \\
\hline
\end{tabular}

Table (5): Summary of the best reduction in ion concentration sea water and bacterial protein content of all optimal parameters for desalination by combination of most potent halotolerant bacterial strains viz. S. marismortui BEW45, M. hispanicus BAS47, and H. elongata BAW48.

\begin{tabular}{|c|c|c|c|c|c|c|c|c|c|c|c|c|}
\hline \multirow{3}{*}{ Parameter } & \multicolumn{10}{|c|}{ Ion concentration $(\mathrm{mg} / \mathrm{l})$. } & \multirow{2}{*}{\multicolumn{2}{|c|}{$\begin{array}{l}\text { Protein content } \\
\qquad(\mathrm{mg} / \mathrm{ml}) .\end{array}$}} \\
\hline & \multicolumn{2}{|c|}{$\mathrm{Ca}^{++}$} & \multicolumn{2}{|c|}{$\mathrm{Mg}^{++}$} & \multicolumn{2}{|c|}{$\mathrm{Cl}^{-}$} & \multicolumn{2}{|c|}{$\mathrm{Na}^{+}$} & \multicolumn{2}{|c|}{$\mathrm{K}^{+}$} & & \\
\hline & Cont. & Treat. & Cont. & Treat. & Cont. & Treat. & Cont. & Treat. & Cont. & Treat. & Control & Treat. \\
\hline $\begin{array}{l}\text { Incubation period } \\
\text { (168 hours). }\end{array}$ & 511 & 414 & 3119 & 2911 & 19674 & 19619 & 11475 & 10533 & 2665 & 1451 & 0.00 & $0.426 \pm 0.036$ \\
\hline $\begin{array}{l}\text { Bottle capacity } \\
(250 \mathrm{ml}) \text {. }\end{array}$ & 561 & 321 & 3087 & 2623 & 20384 & 19674 & 12687 & 11204 & 1074 & 998 & 0.00 & $0.389 \pm 0.011$ \\
\hline $\begin{array}{l}\text { Temperature } \\
\left(37^{\circ} \mathrm{C}\right) .\end{array}$ & 561 & 321 & 3087 & 2623 & 20384 & 19674 & 12687 & 11204 & 1074 & 996 & 0.00 & $0.411 \pm 0.028$ \\
\hline $\mathrm{pH}(6.0)$. & 781 & 400 & 2954 & 2255 & 19674 & 16661 & 12968 & 12692 & 1096 & 870 & 0.00 & $0.337 \pm 0.023$ \\
\hline $\begin{array}{lr}\text { Inoculum } & (2.5 \\
\text { ml) } & \\
\text { (Each } & \mathrm{ml} \\
\text { contained } & \\
\left.67 \mathrm{X} 10^{7} \mathrm{CFU}\right) & \\
\end{array}$ & 882 & 500 & 3380 & 3015 & 20561 & 18788 & 12678 & 11785 & 951 & 882 & 0.00 & $0.364 \pm 0.016$ \\
\hline $\begin{array}{l}\text { Nitrogen source } \\
\text { (yeast extract). }\end{array}$ & 744 & 350 & 3258 & 2982 & 22333 & 20383 & 13002 & 11820 & 967 & 956 & 0.00 & $0.313 \pm 0.017$ \\
\hline $\begin{array}{c}\text { Shaking } \\
\text { condition at } 100 \\
\text { rpm }\end{array}$ & 882 & 437 & 3380 & 2492 & 20561 & 15302 & 12678 & 6982 & 951 & 665 & 0.00 & $0.341 \pm 0.008$ \\
\hline
\end{tabular}


Table (6): Summary of reduction of ion values (\%) in sea water under all optimal parameters for desalination by combination of potent halotolerant bacterial strains viz. $S$. marismortuiBEW45, M. hispanicusBAS47, and $H$. elongataBAW48.

\begin{tabular}{|c|c|c|c|c|c|c|c|c|c|c|}
\hline \multirow{3}{*}{ Parameter } & \multicolumn{10}{|c|}{ Ions reduction value $(\%)$} \\
\hline & \multicolumn{2}{|c|}{$\mathrm{Ca}^{++}$} & \multicolumn{2}{|c|}{$\mathrm{Mg}^{++}$} & \multicolumn{2}{|c|}{$\mathrm{Cl}^{-}$} & \multicolumn{2}{|c|}{$\mathrm{Na}^{+}$} & \multicolumn{2}{|c|}{$\mathrm{K}^{+}$} \\
\hline & Cont & Treat & Cont & Treat & Cont & Treat & Cont & Treat & Cont & Treat \\
\hline $\begin{array}{ll}\text { Incubation } & \text { period } \\
\text { (168 hours). } & \end{array}$ & 100 & 19 & 100 & 7 & 100 & 0.3 & 100 & 8 & 100 & 45 \\
\hline $\begin{array}{l}\text { Bottle capacity } \\
(250 \mathrm{ml}) \text {. }\end{array}$ & 100 & 43 & 100 & 15 & 100 & 4 & 100 & 12 & 100 & 7 \\
\hline Temperature $\left(37^{\circ} \mathrm{C}\right)$. & 100 & 43 & 100 & 15 & 100 & 4 & 100 & 12 & 100 & 7 \\
\hline pH 6.0 & 100 & 49 & 100 & 24 & 100 & 15 & 100 & 2 & 100 & 20 \\
\hline $\begin{array}{l}\text { Inoculum size } \\
(2.5 \mathrm{ml}) .\end{array}$ & 100 & 43 & 100 & 11 & 100 & 8.6 & 100 & 7 & 100 & 7.3 \\
\hline $\begin{array}{l}\text { Nitrogen source (yeast } \\
\text { extract). }\end{array}$ & 100 & 53 & 100 & 8.5 & 100 & 8.7 & 100 & 9.1 & 100 & 1.1 \\
\hline $\begin{array}{l}\text { Shaking conditions at } \\
100 \mathrm{rpm}\end{array}$ & 100 & 51 & 100 & 26 & 100 & 26 & 100 & 45 & 100 & 30 \\
\hline
\end{tabular}

Table (7): Determination of ions concentration after bacterial desalination of sea water by combination of $S$. marismortui BEW45, M. hispanicus BAS47, and $H$. elongata BAW48 for several treatments.

\begin{tabular}{|c|c|c|c|c|c|}
\hline \multirow{2}{*}{ Treatment stage } & \multicolumn{5}{|c|}{ Ions concentration $(\mathrm{mg} / \mathrm{l})}$. \\
\cline { 2 - 6 } & $\mathrm{Ca}^{++}$ & $\mathrm{Mg}^{++}$ & $\mathrm{Cl}^{-}$ & $\mathrm{Na}^{+}$ & $\mathrm{K}^{+}$ \\
\hline Control & 940 & 3781 & 24822 & 11880 & 983 \\
\hline First step & 489 & 2458 & 15638 & 7247 & 668 \\
\hline Second step & 197 & 1247 & 7943 & 3445 & 423 \\
\hline Third step & 113 & 832 & 5213 & 2832 & 315 \\
\hline
\end{tabular}

Table (8): Effect of repeated seawater bacterial desalination on the growth and pigments of Hordeum vulgare Giza 2 after 21 days of irrigation.

\begin{tabular}{||l|c|c||}
\hline \multicolumn{1}{|c|}{ Parameter } & $\begin{array}{c}\text { Control } \\
\text { (Tap water). }\end{array}$ & $\begin{array}{c}\text { Desalinated sea } \\
\text { water. }\end{array}$ \\
\hline Shoot length $(\mathrm{cm})$. & $5.7 \pm 0.264$ & $4.863 \pm 0.123$ \\
\hline Root length $(\mathrm{cm})$. & $10.66 \pm 0.104$ & $6.633 \pm 0.550$ \\
\hline Plant weight $(\mathrm{g})$. & $0.75 \pm 0.21$ & $0.603 \pm 0.011$ \\
\hline Chlorophyll a $(\mathrm{mg} / \mathrm{g})$. & $7.7 \pm 0.173$ & $6.1 \pm 0.404$ \\
\hline Chlorophyll b $(\mathrm{mg} / \mathrm{g})$ & $4.43 \pm 0.02$ & $4.41 \pm 0.242$ \\
\hline Carotenoid. $(\mathrm{mg} / \mathrm{g})$. & $2.5 \pm 0.264$ & $2.173 \pm 0.125$ \\
\hline
\end{tabular}




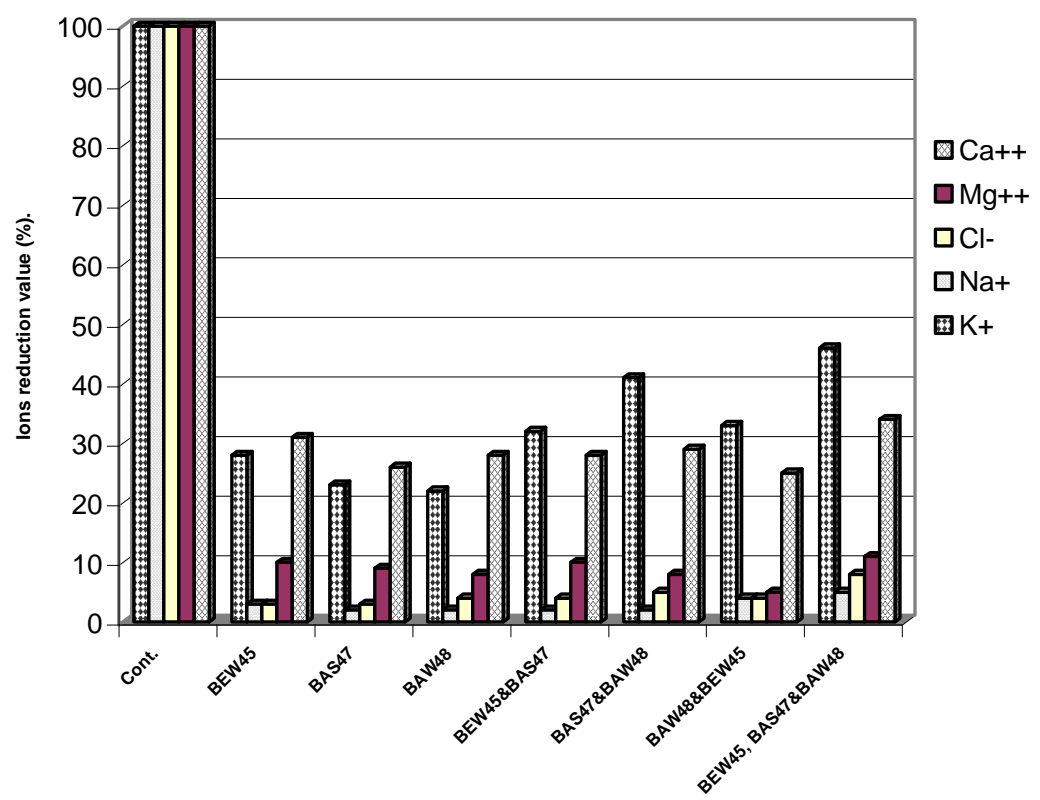

Bacterial combination.

Figure (1): Determination of reduction ions $(\%)$ of ions in sea water by the combination of three most potent bacterial strains.

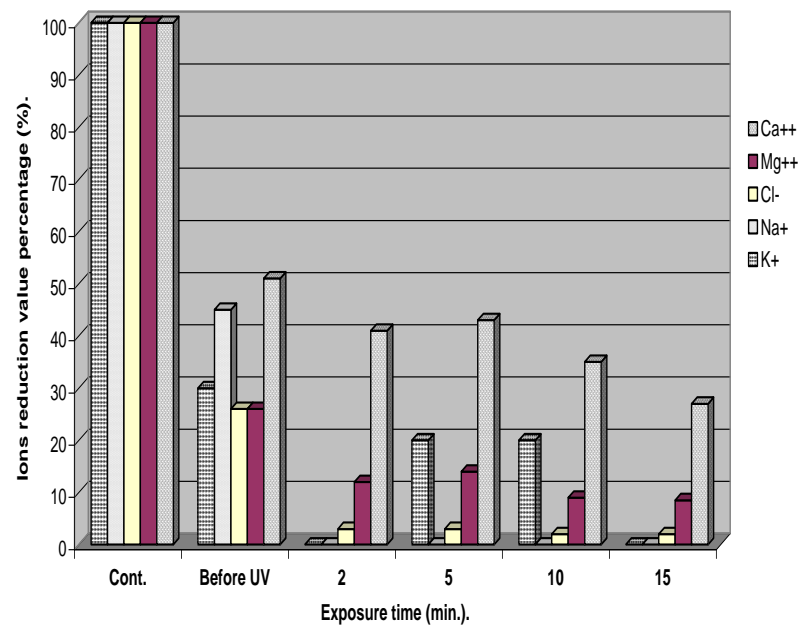

Figure (2): Determination of reduction (\%) of ions in sea water by the combination of $S$. marismortui BEW45, M. hispanicus (BAS47), and H. elongata BAW48 due to UV-irradiation. 


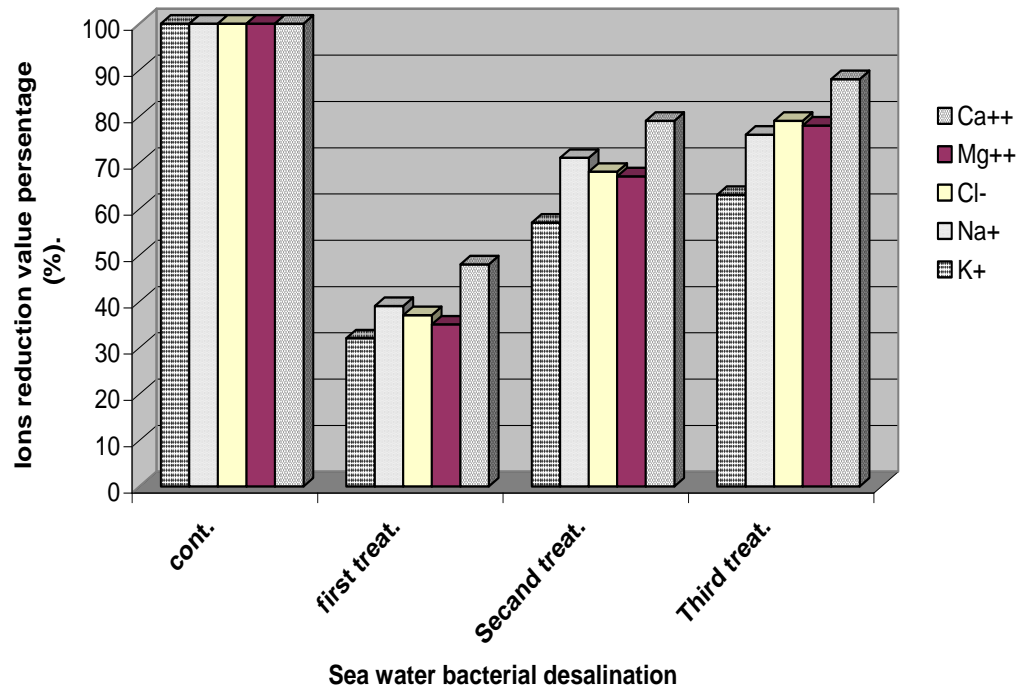

Figure (3): Determination of reduced ions $(\%)$ in repeated sea water by repeated desalination using the combination of $S$. marismortui BEW45, $M$. hispanicus BAS47 and $H$. elongata BAW48.

\section{References}

1. Ammar, M.S.; and Muharram, M.M. (1998): Application of microbial biotechnology in sea water desalination in Egypt AQUA-Tec 98, Cairo, Dec. $3^{\text {rd }}-5^{\text {th }}, 98: 1-13$.

2. Ammar, M.S.; Azab, M.S.; and Muharram, M.M. (2000): Desalination of sea water using a biologically controlled microbial system. Egypt J. Biotechnol. Vol. 8: 76 - 87.

3. Blum, J. S.; Stolz, J. F.; Oren, A. and Oremland, R. S. (2001): Selenihalanaerobacter shriftii gen. nov., A halophilic anaerobe from sea sediments that respires selenate. Arch. Microbiol. 175: 208 - 219.

4. Cotruvo,J.A.(2004): Desalination Guidelines Development for Drinking Water. Rolling Revision of the WHO Guidelines for Drinking -Water Quality. WHO-August 2004.

5. Cotruvo,J.A.(2007): Desalination Guidelines Development for Drinking Water. Rolling Revision of the WHO Guidelines for Drinking -Water Quality. WHO-August 2007.

6. Das-Sarma,S. and Arora,P.(2001): A general review on Halophiles. In Encyclopedia of life sciences. Nature publishing group/ www.els.net.

7. Dennis,P.P. and Shimmin,L.C.(1997): Evolutionary divergene and salinity- mediated selection in halophilic archaea. Microbial Molecular Biology. Review.61:90-104.

8. Fetter, C. W. (2001): Applied hydrogeology Charles E. Merrill publishing company London pp. $1-5$. 
9. Gandbhir, M.; Rasched, I.; Marliere, P. and Mutzel, R. (1995): Convergent evolution of amino acid usage in archaebacterial and eubacterial lineages adapted to high salt. Res. Microbiol. Vol. 146, 113-120.

10. Holt, I. G.; Kreig, N. R.; Sneath, P. H. A.; Stanely. J. T. and Williams, S. T. (1994): Bergey's Manual of Determinative Bacteriology, $9^{\text {th }}$. Edition, Williams and Wilkins, Publishers, Baltimore.

11. Jeffery, G. H.; Bassett, J.; Mendham, J. and Denney, R. C. (1989): Vogel's textbook of quantitative chemical analysis. Johan Wiley and Sons, Inc., New York. P.324-352.

12. Johnsen, U.; Selig, M.; Xavier, K. B.; Santos, H. and Schonheit, P. (2001): Different glycolytic pathways for glucose and fructose in the halophilic archaeon Halococcus saccharolyticus. Arch Microbiol, 175: 52 - 61 .

13. Kargi, F.; and Dincer, A. R. (1998): Saline wastewater treatment by halophilic supplemented activated sludge culture in an aerated rotating biodisc contactor. Enzyme and Microbiol. Technol. 22: 427-433.

14. KerKar,S.(2004): Studies on bacteria of the dissimilatory reductive processes of the sulphur cycle from the salt pans of Goa. Ph.D.Thesis, Dept. of Marine Sciences, Goa University.

15. Larsen, H. (1981): The family of Halobacteriacae, pp. 985-994 In (Starr, M.P., Stolp, H., Truper, H.G.; Balows, A. and Schlegel, H.G.) (Editors), The prokaryotes: A.H and book on Habitats, Isolation and Identification of Bacteria, Vol. 1, Springer-Verlag, New York.

16. Lowry, O.H.; Rosenbrough, N.J.; Farr, A.L., and Randall, R.J. (1951): Protein measurement with Folin Phenol reagent. J. Biol. Chem. 193: 265-275.

17. Muharram, M. M. (2000): Desalination of sea water using a biologically controlled microbial system. M.Sc. thesis, Fac. Of sci., Al-Azhar Univ., Cairo, Egypt.

18. Oren, A.; Weis Burg, Kessel, M. and Woese, C. R. (1995): Halobacteroides halobius gen. Nov., sp. Nov., a moderately halophilic anaerobic elongata from the bottom sediments of the Dead Sea. Syst Appl. Microbiol 5: 57 - 70.

19. Patel, S.; Jain, N. and madamwar, D. (1993): Production of $\alpha$-amylase from Halobacterium halobium. World. J. Microbiol. Biotechnol. 9: 25 - 28.

20. Qasim, S. R.(1999): Water treatment plants: Planning, design, and operation, $2^{\text {nd }}$ ed., Economic publishing Co., Inc., Lancaster, PA,.

21. Qasim, S. R.; Motly, E. M.; and Zhu, G. (2000): Water works engineering planning, design and operation. Prentice - hall PTR. Upper suddle River 757 - 766.

22. Spang,E.(2006):The potential for wind-powered desalination in water-scarce countries. M.Sc. The Fletcher School. Tufts Univ. 
23. Studdert, C. A.; De Castro, R. E.; Seitz, K. H. and Sanchez, J. J. (1997): Detection and preliminary characterization of extracellular proteolytic activities of the aloalkalophilic archaeon Natronococcus occultus. Arch. Microbiol. 168: 532 - 535.

24. Ventosa,A.;Marquez,M.C.;Garabito,M.J.and Arahal,D.R.(1998):Moderately halophilic Gram-positive bacterial diversity in hypersaline environments. Extremophiles.2:297-309.

25. Vreeland, R. H.; Diagle, S. L.; Field, S. T.; Hart, D. J. and Martin, E. L. (1991): Physiology Halomonas elongata in different $\mathrm{NaCl}$ concentrations. In: Rodriguez-Valera, F (ed), General and applied aspects of halophilic microorganisms. Plenum Press, New York, pp. $233-241$.

26. Yoshitaka,K.;Shiro,I.; Shoichi,A. and Yuji,O.(2005): Development of pretreatment for reverse osmosis desalination seawater with biological activated carbon. Hitach Zosen Technical. Review. 66(1):34-37. 


\section{نظم بكتيريولوجية كاتجاه جديد لإزالة ملوحة المياه المالحة}

رضا احمد بيومى , سميرصلاح اللبودى, ممدوح سالم الجمل , محمد عبد الواحد من

قسم النبات وإلميكروبيولوجى - كلية العوم(بنين)- جامعة الأزهـر - مدينة نصر -القاهرة-

$$
\text { الرقم البريدى: }
$$

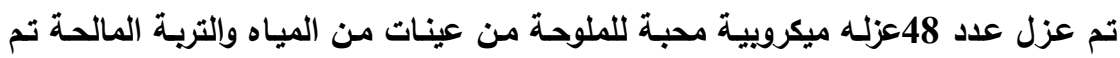

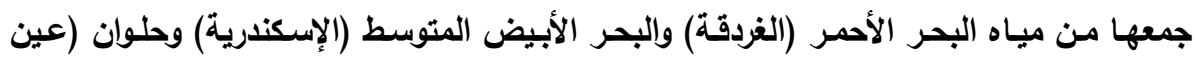

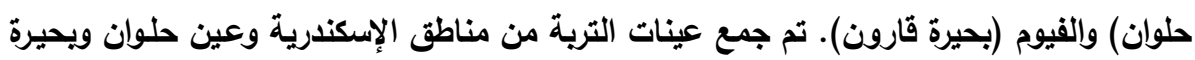

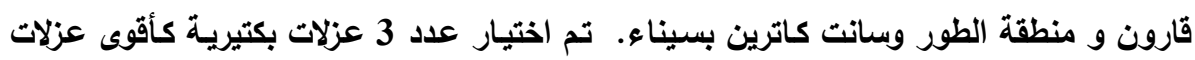

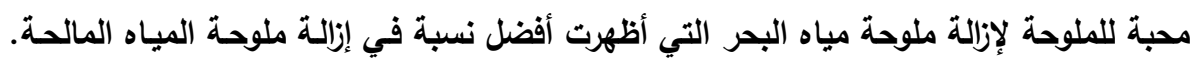

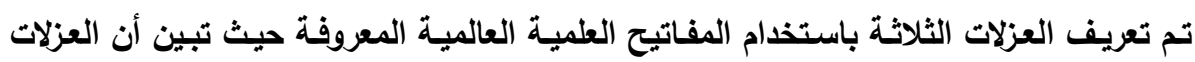
تنتمس إلسى: سـبوروهالويكتر مساريزمورتي BEW45 Sporohalobacter marismortui ومـارينوكوكس هيسبانيكس Marinococcus hispanicus BEW47 وهالوموناس الونجاتا Halomonas elongataBAW48. اظهر الخلط بين العزلات البكتيرية الثُلاثة المحبة للملوحة نسبة إزالة عالية للملوحة. أفضل نسبة ازالة للملوحة تم الحصول عليها بواسطة خليط البكتيريا

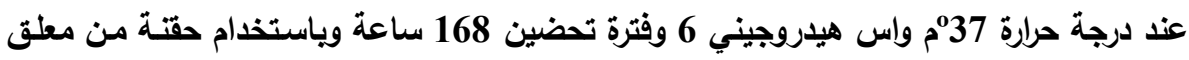

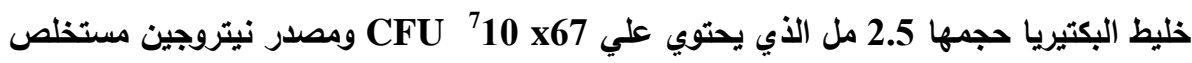

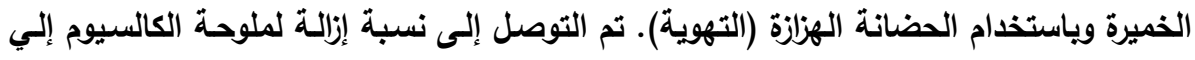

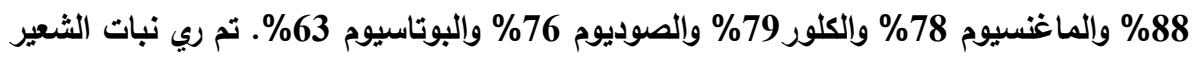

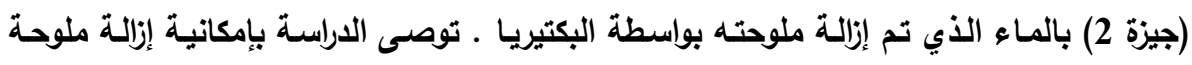

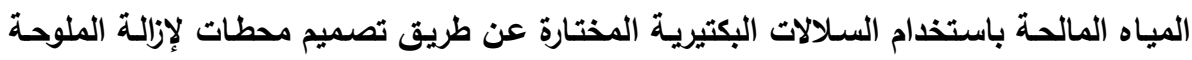

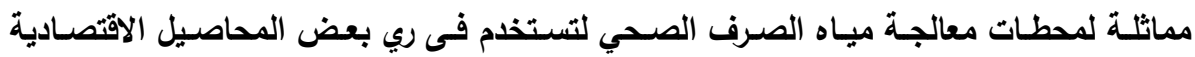
وأثثجار الغابات الخثبية. 